\title{
オブジェクト分類手法による詳細土地被覆情報 の取得と地表面温度の再現性に関する研究
}

\author{
大西 暁生 ${ }^{*} \cdot$ 前崎 隆一 2 \\ 1東京都市大学環境学部環境創生学科（テ224-8551 神奈川県横浜市都筑区牛久保西3-3-1） \\ 2公務員（干920-0271 石川県河北郡内灘町鶴ヶ丘2丁目677番地） \\ * E-mail: onishi@tcu.ac.jp
}

\begin{abstract}
都市部では，郊外と比べ熱環境が悪化するヒートアイランド現象が問題となっている. その一つの要因 として, 都市内部の土地被覆が大きく関わっている。とりわけ，コンクリートやアスファルトといった人 工的な被覆が増加することによって熱環境が悪化している. そのため本研究では, 近年注目されているオ ブジェクト分類手法を用いて詳細土地被覆情報を取得するとともに，その精度の検証を現地の情報と照ら し合わせて行い, 従来のピクセルベースの分類手法によって得られた結果と比較することでその精度の高 さを示す.さらに, 熱環境が悪化する夏季の昼間を対象に, 土地被覆割合が地表面温度に与える影響を通 常の回帰分析（OLS: Ordinary Least Squares）とGWR (Geographically Weighted Regression, 地理的加重回帰 法）によって明らかにする。そしてここで得られた関係式を用いて地表面温度を推計することによって， その再現性をASTER衛星画像の地表面温度と比較することで検証する。
\end{abstract}

Key Words : land cover classification, fine lond covers, land surface temperature

\section{1. はじめに}

都市内部の熱環境が郊外部に比べ悪化するヒートアイ ランド現象が著しくなっている，この原因の根幹は，自 動車やエアコンなどからの人工排熱，高層ビル群による 風の流れの変化や帯留, 都市特有の建築物の高密度化と いった地域特性，そして水域や緑地といった自然的な土 地被覆の減少並びにアスファルトやコンクリートといっ た人工的な土地被覆の増加があげられている。このよう な問題を緩和するため，今まで様々な対策が打ち出され てきた. 人工排熱の要因については，住宅，オフィスな どでの空調, 自動車の運転および工業生産のための電気, ガス, 油などのエネルギー消費により, 最終的には熱と して大気に放出されることでヒートアイランド現象を助 長している1)。こうしたエネルギー消費に伴う排熱をヒ 一トアイランドの「二次破壊系要因」2)とし，鳴海ら²は 都市における人工排熱 (廃熱) が都市熱環境に及ぼす影 響に関して検討を行っている．現在では，自動車から鉄 道やバスといった公共交通機関へのモーダルシフトや, 省エ市製品の普及も広い意味では人工排熱の対策の一つ である. 地域特性の要因として，例えば東京では多くの
中小河川が暗渠化され，改修されて水面の占める割合が 大きく減っていることから, 水面からの蒸発による気化 熱の効果も弱まっている4). そのため, 都市開発によっ て地下に埋められてしまった用水路や小川を復活させ, 水の流れ，風の流れを取り戻すことを目的とした事業が 国内外の都市，例えば韓国ソウル市の清渓川55よ゙で行 われている. しかし，上記の対策には補助金や建設費と いったコストがかかる恐れがある. そこで一般的に注目 されているのが土地被覆の緑化である. コンクリート建 造物やアスファルト舗装道路で覆われた都市の地表面は， 森林・草地や田畑・裸地が主体の郊外田園地帯とは, 熱 容量・熱伝導などの熱的特性, および蒸発効率や反射 率・射出率などの放射特性が異なる4). そのため, 人工 被覆を緑地に置き換えることによって，もともとの人工 被覆による日射エネルギーの吸収と放射熱が抑えられる と同時に，植物を配置することによって蒸発散が促進さ れ，これによって昇温抑制効果も得られる。 また，樹木 などの背の高い植物によって緑化すれば，その影により 日陰の効果も得られ，これによって都市の熱環境を緩和 する効果が得られる. 東京都では2001年から「東京にお ける自然の保護と回復に関寸る条例（自然保護条例）」 
に基づき， $1,000 \mathrm{~m}^{2}$ 以上（公共施設は $250 \mathrm{~m}^{2}$ 以上）の敷地 において，建築物を新築又は増改築などの時に，敷地と 建築物上（屋上・壁面・ベランダなど）に緑化を義務付 け，緑の回復を行っているの。他の自治体も屋上緑化な どの義務化をはじめ，例えば2002年に兵庫県6，2006年 に大阪府6，2007年に京都府)，2008年に名古屋市の「緑 化地域制度」7などの事例がある。この事業には助成金 が出されるなど, 緑化が徐々に推進されている. その他 にも，屋根などに高反射率塗料を塗布するなどの研究8), 9)が行われることで対策が進み, 熱環境の緩和が促進さ れている．本研究の対象地域である富山市では，市民の 新たな交通手段として2006年4月からLRT（Light Rail Transit）が富山ライトレールとして運行している. 全国 各地でもLRTは運用され，軌道敷内に緑地を設置する工 夫が多く存在する. このように, 都市内の緑地の被覆率 を広げていこうとする取り組みが実施されている. その ためまず, 都市内部に点在する緑地などの土地被覆を詳 細且つ正確に把握する必要がある.

従来の衛星画像であるLANDSATなどを用いて, 土地 被覆や土地利用と気温または地表面温度との関係を分析 した研究として, 天野・中川10), 渡辺ら ${ }^{11)}$, 円満・尾島 12)がある。ただし，LANDSATなどの衛星画像の解像度 は数十 $\mathrm{m}$ と粗く, 近年では前述したような微細な緑地な どの状況を詳細に把握する目的から，高分解能な衛星画 像が用いられはじめている。 そのため, 筆者ら 13)-18),

Onishi et al. ${ }^{19)}$, 廣田 ${ }^{20)}$, Cao et al. ${ }^{21)}$, 吉川 ${ }^{22)}$, 上野・井 村23) は高分解能衛星画像の一つであるIKONOSを利用し, 詳細な緑地や土地被覆を取得する手法を検討し，これを 熱環境の解析に応用してきた。特に，IKONOSから取得 した土地被覆とLANDSATやASTERから得られた地表面 温度 (LST: Land Surface Temperature) の関係を統計的な手 法である重回帰分析（最小二乗法） (OLS : Ordinary Least Squares）などによって把握してきた.この手法は, 地表 面温度と土地被覆の関係を簡便に把握寸るには有用な手 法である.しかし，このような手法を用いて得られる地 表面温度に対する各土地被覆の影響度合いを表す係数は, 観測地点において一定と仮定した平均的な傾向を表すも のである。また，熱収支式などの物理的な方法によって 地表面温度や気温を再現する場合にも，各地点の特性を 表わすパラメータを地点の特徴を加味して変えない限り 算出される気温へのパラメータの影響は空間的に一様と なる. そのため, 筆者ら ${ }^{24}$ は従前の研究17), 19)で得られた 詳細な樹木や草地といったデータと名古屋市の都市計画 基礎調査の土地利用データを組み合わせることによって, 地域の空間的な特性を加味することができる新たな統計 的な手法であるGWR (Geographically Weighted Regression, 地理的加重回帰法) を熱環境の解析に試みてきた。また，
Buyantuyev and $\mathrm{Wu}^{25)}$ は，筆者らと同様の視点を持ち，地 表面温度と土地の特性の関係をGWRを用いて分析して いる. また，熱環境の解析ではないが，奥岡ら20は名古 屋市を対象に, 神社や緑地といった環境資源要素の価值 をOLSとGWRによって分析している.ただし，従前の 研究ではIKONOSによる分類が, 従来のピクセルベース で行っていたことや，GWRを分析に用いた場合にも IKONOSから利用したのは樹木と草地のみであったこと など多くの課題が残された.

そのため本研究では, 熱環境の原因となる土地被覆を 詳細に取得するため, 既存のピクセルベースである教師 なし分類手法, 教師あり分類手法, エキスパート分類手 法ではなく, 比較的新しい分類手法として近年利用され はじめているオブジェクト分類手法を用いる. そして， このオブジェクト分類手法を用いて得られた土地被覆の 結果の精度検証を現地の情報と照らし合わせて行うと同 時に, 我々が以前に行ったピクセルベースの結果 ${ }^{27)}$ と比 較することによってその精度の高さを示す.さらに, こ の土地被覆分類の結果を用いて, 熱環境が悪化する夏季 の昼間における地表面温度との関係を明らかにする。 そ の際，OLS だけではなく, 観測地点の距離を重み付け とするGWRを用いることによって地域固有の係数を得 る. 最終的には，これら異なる関係式を用いて地表面温 度を推計し，その違いをASTER衛星画像の地表面温度 と比較することでその再現性を検証する. これによって 今後, 詳細且つ精度の高い土地被覆の情報を取得する方 法を提示するとともに，その地表面温度との関係を把握 するための新たな方法を示す.

\section{2. 使用データと対象地域}

土地被覆分類で使用した衛星画像は，高分解能衛星の 一つであるIKONOS画像である，IKONOSは，米国の偵 察衛星技術を用いて造られたものであり，撮影したい場 所を的確に捉えることができるとともに，周回衛星のた め時間変化に伴う土地被覆の遷移などを把握することが できる. 最大の特徴は，分解能が $1 \mathrm{~m}$ 高いこと（衛星 画像の 1 ピクセルが地上の距離の約 $1 \mathrm{~m}$ に相当すること） である.これによって，従来の衛星では判別することが 困難であった街路の樹木や一般住宅の庭木など面積の小 さい緑地を把握することが可能となる．ただし， IKONOSのセンサは可視域の青・緑・赤と, 近赤外の4 つのバンドで構成されており, 例えば一般によく使用さ れるLANDSAT (ETM+は8バンド) と比較しても, 利用 できる波長域は狭くなっている. そのため, 地表面温度 画像で使用したのはASTER衛星のものである. ASTER 
は，可視光から熱赤外までの14バンドを有しており，本 研究で使用した地表面温度以外にも地表面放射率や地表 面反射率といった様々な地表面の情報が整備されている。 ASTERの分解能はプロダクトにより異なるが，ここで 用いた地表面温度画像の分解能は約 $90 \mathrm{~m}$ である.

本研究の対象地域は，使用したIKONOS画像に合わせ， 富山市の中心部を含む経度 $137^{\circ} 09^{\prime} \quad 49^{\prime \prime} \sim 137^{\circ} 13^{\prime}$ $42^{\prime \prime}$ ，緯度 $36^{\circ} 39^{\prime} 46^{\prime \prime} \sim 36^{\circ} 42^{\prime} 09^{\prime \prime}$ であり，その範 囲は5,773m×4,430mとなっており，面積は25.57 $\mathrm{km}^{2}$ であ る. 撮影日時は，2006年8月1日午前10時59分（JST : Japan Standard Time，日本標準時）の画像である． ASTER については，範囲をIKONOSに合わせて用いている．撮 影日時は，2010年8月30日10時45分（JST）である.

\section{3. 詳細土地被覆情報の取得}

\section{(1) 既存の土地被覆分類手法}

現在，一般的に用いられる土地被覆分類手法として， ピクセルベースの教師なし分類手法, 教師あり分類手法, エキスパート分類手法がある。また最近では，土地被覆 をグループとして扱うオブジェクト分類手法が広く利用 されはじめている。筆者ら ${ }^{27}$ は，すでに富山市の IKONOSを用いて，ピクセルベースによる3つの分類手 法を行い，詳細な土地被覆分類情報を取得している. そ して，これら3つの取得結果について精度検証を現地の 情報と照らし合わせて行っている，次章では本研究にお けるオブジェクトベースの分類結果と現地の情報を照ら し合わせることによって精度検証を行うとともに，上記 の既存研究の結果と比較することでその精度の高さを示 す. 以下にピクセルベースの分類手法について補足とし て説明を簡単に加えておく.

教師なし分類手法とは，任意のクラスタ数をあらか じめ設定することにより，コンピュータが自動的にクラ スタリングする手法であり, 最終的に各クラスタと土地 被覆分類項目（クラス）を対応づける手法である27).

教師付き分類手法とは，現地調査などで得られた現 地の土地被覆の情報（トレーニングデータ = 教師デー タ）を用いて分類する手法である27)。例えば，現地にお いて緑地と判明した地点のトレーニングデータをもとに この教師データのスペクトル特性を判別し，類似したス ペクトル特性をもつ土地被覆を同様に緑地として分類し ていく手法である27.

エキスパート分類手法は, 各土地被覆項目のトレー ニングデータからスペクトル特性を判読し, 各土地被覆 項目の特性を分類の一つの条件（ルール）として加えて 設定し分類するものである ${ }^{27)}$. 教師付き分類手法よりも
詳しくスペクトルの特性を読み取って行うため, 教師付 き分類手法で発生した誤分類項目を正しく分類すること ができる27. しかし，上記の3つの分類手法はピクセル ベースで分類を行うため, ゴマ塩状の微小な誤分類（微 小領域）が多く発生する問題がある. そのため本研究で は，前述したオブジェクト分類手法を用いて，さらなる 精度向上を試みる. ピクセルベースにおける分類の説明 の詳細と得られた結果については，我々の論文27を参考 にされたい.

\section{(2) オブジェクト分類手法}

ピクセルベースにおける分類手法は，微小領域と言わ れるゴマ塩状の誤分類が発生し, 分類精度の低下につな がる. そのため本研究では，この問題を解決するため, オブジェクト分類手法を用いて改善を試みる.この分類 手法の特徴は, 分類対象をオブジェクトとみなすため微 小領域が発生せず，分類結果の被覆の境界が明確になる ことが挙げられている.

この手法は, はじめにスケールレベル（オブジェクト サイズのパラメータ）を決定し，マージレベル（微小な オブジェクトを統合するパラメータ）を決定する. スケ 一ルレベルによりオブジェクトの大きさが決定できるが， スケールレベルが小さい場合はオブジェクトは小さく均 質性が高いものになり，他方，スケールレベルが大きい 場合はオブジェクトは大きく均質性が低下する ${ }^{28)}$. マー ジレベルでは，スケールレベルで分割されたオブジェク 卜を結合することを意味し，この值が大きければ，広い 近隣の範囲で同じ特性を持つオブジェクトを結合する ${ }^{29}$. ここでは，森林や河川といった大きなオブジェクトか ら，住宅の屋根といった小さいサイズのオブジェクトま で発生するため, スケールレベルを28.0, マージレベル を40.2に設定した. 設定方法としては，オブジェクトを 何度か作成し直し, 設定した11項目の土地被覆分類に最 も適合するパラメータを試行錯誤的に見つけた. オブジ エクト分類手法には，ルールベースの分類手法と教師付 き分類の手法があるが，ここでは後者を用いた．教師付 き分類の手順は前述のピクセルベースのものと同様であ り, 現地調査などから得られた情報をもとに, オブジェ クトを選択し分類クラスを割り当てた後に分類を実行し た.

最終的なオブジェクト分類による対象地域全体の分類 画像及び富山城, 布瀬南, 陸上競技場の分類画像を図-1 に示す。また，対象地域全体の土地被覆面積割合を図-2 に示す.

\section{(3) 精度検証とピクセルベースの結果との比較}

ここでは，本研究で行ったオブジェクト手法による分 


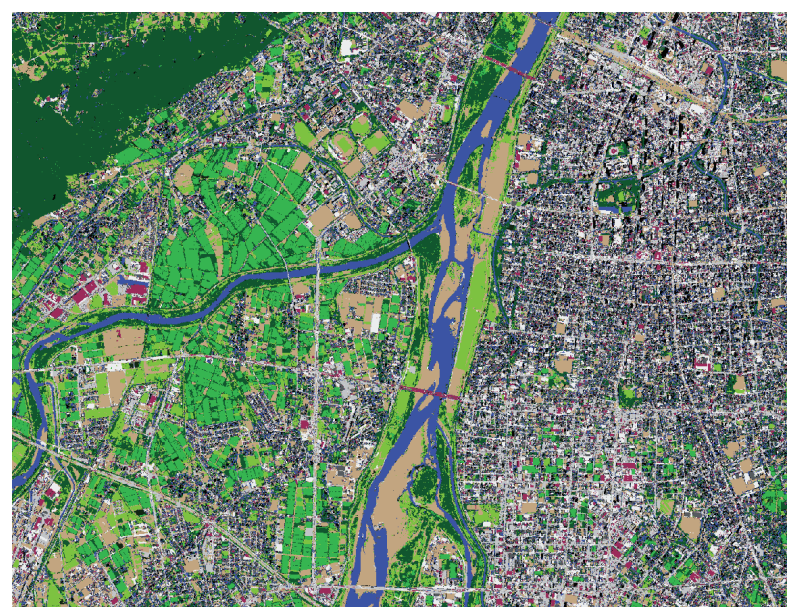

対象地域全体

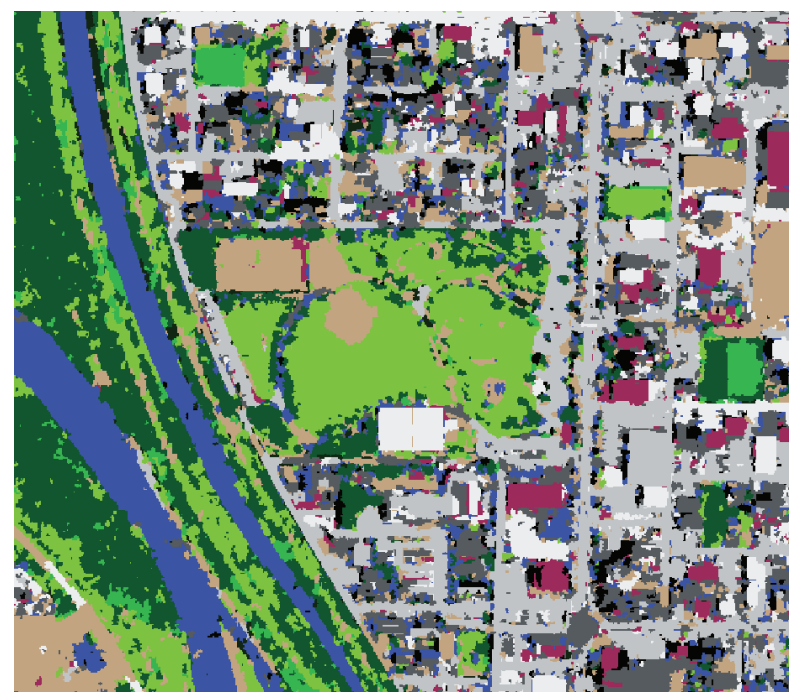

布瀬南公園

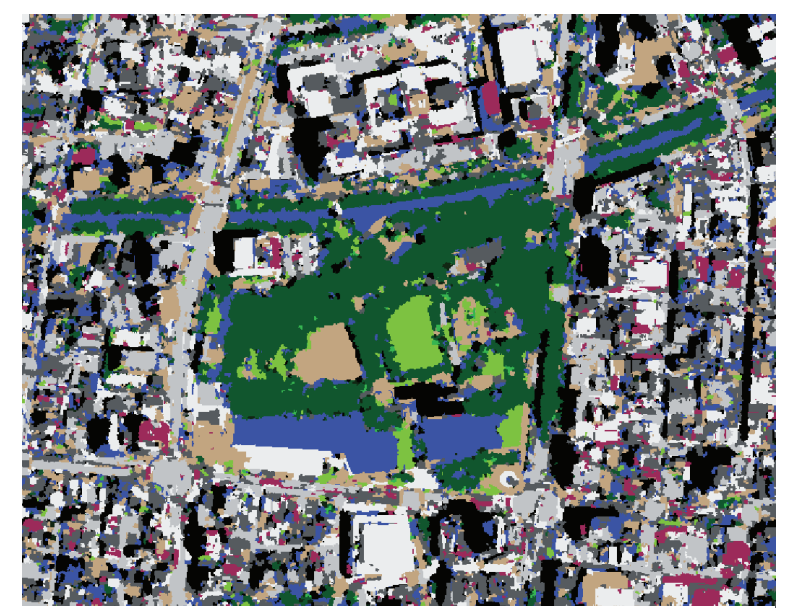

富山城

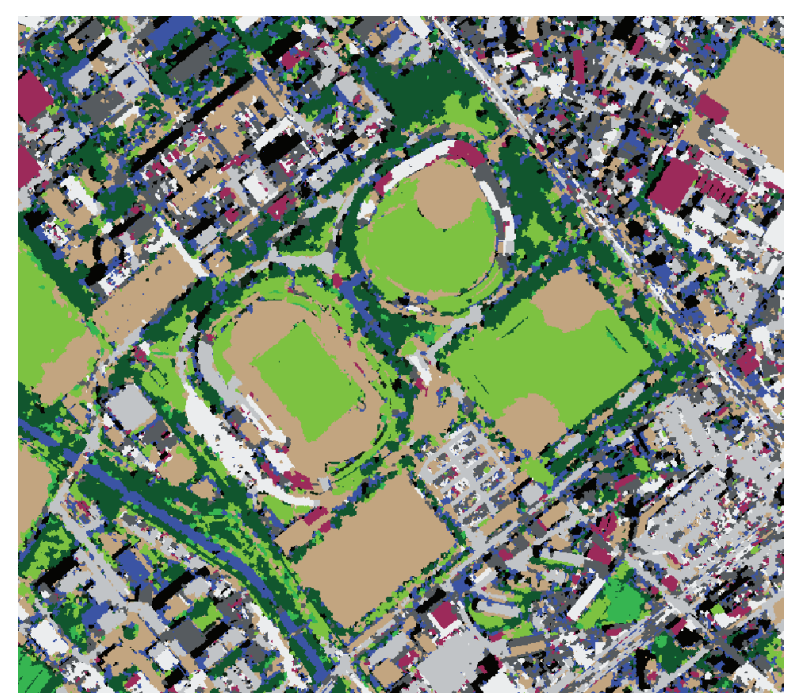

陸上競技場

\begin{tabular}{|c|c|c|c|c|c|c|}
\hline \multirow{3}{*}{ 凡例 } & 水域 & 影域 & 水田 & 畑 & 樹木 & 草地 \\
\hline & & & & & & \\
\hline & 土堙 & アスファルト & コンクリート & 凡厔根 & 金盾 & \\
\hline
\end{tabular}

図-1 オブジェクト分類による画像

類結果を現地調查で確認した実際の土地被覆と照らし合 わせることで精度検証を行う。検証方法はランダムに 165地点を選定し，現地調査を行い実際の土地被覆を把 握した. そのポイントデータと結果画像を重ね合わせて 検証する. また, 我々が以前に行ったピクセルベースの 結果27) と比較することによってその精度の高さを示す. 表-1に, 精度検証の結果を示寸。

得られた結果として, 全体精度を見ると, 教師なし分 類, 教師付き分類, エキスパート分類, オブジェクト分 類の順に精度が向上しており，オブジェクト分類手法の 全体精度が84.24\%と，ピクセルベースの中でも最も精度 が高かったエキスパート分類結果と比べて $10 \%$ 近く精度 が向上していることが分かった．とりわけ，樹木の精度 が94.12\%と非常に高いことが分かる．また，エキスパー

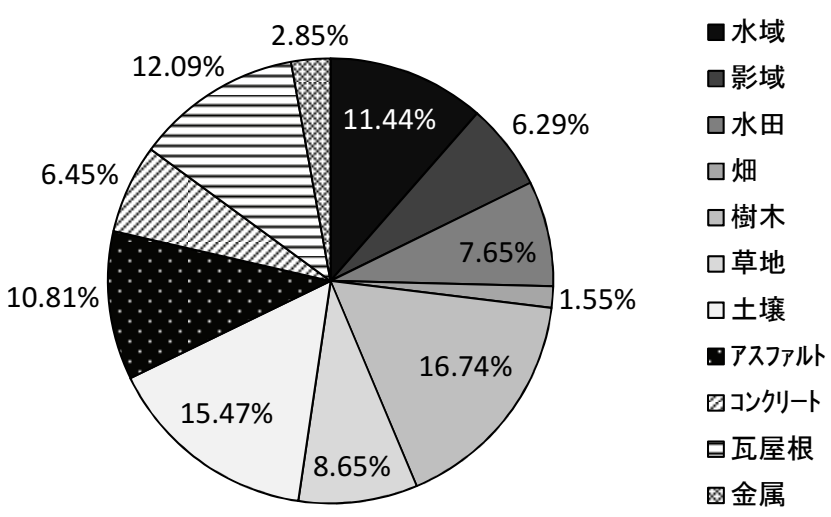

図-2 対象地域全体の土地被覆面積割合 
表-1 精度検証の結果

\begin{tabular}{|c|c|c|c|c|c|c|}
\hline 分類手法 分類䛃 & 水域 & 影域 & 水田 & 畑 & 樹木 & 草地 \\
\hline 教師なし & $66.67 \%$ & $93.33 \%$ & $86.67 \%$ & $0.00 \%$ & $46.67 \%$ & $33.33 \%$ \\
\hline 教師あり & $86.67 \%$ & $86.67 \%$ & $100.0 \%$ & $20.00 \%$ & $80.00 \%$ & $26.67 \%$ \\
\hline エキパート & $93.33 \%$ & $75.00 \%$ & $93.33 \%$ & $53.33 \%$ & $80.00 \%$ & $86.67 \%$ \\
\hline オブジ外 & $93.75 \%$ & $93.75 \%$ & $87.50 \%$ & $87.50 \%$ & $94.12 \%$ & $85.71 \%$ \\
\hline 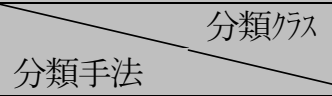 & 土壌 & アスファル & コンクリート & 瓦屋根 & 金属 & $\begin{array}{l}\text { 全体 } \\
\text { 精度 }\end{array}$ \\
\hline 教師なし & $46.67 \%$ & $86.67 \%$ & $60.00 \%$ & $0.00 \%$ & $33.33 \%$ & $50.30 \%$ \\
\hline 教師あり & $66.67 \%$ & $100.0 \%$ & $80.00 \%$ & $60.00 \%$ & $53.33 \%$ & $69.09 \%$ \\
\hline エキスパート & $60.00 \%$ & $93.33 \%$ & $66.67 \%$ & $60.00 \%$ & $60.00 \%$ & $75.76 \%$ \\
\hline オブジェ外 & $81.25 \%$ & $73.33 \%$ & $80.00 \%$ & $72.22 \%$ & $76.92 \%$ & $84.24 \%$ \\
\hline
\end{tabular}

教師なし，教師あり，エキスパートについては筆者らの論文27からの再掲である.

表-2 地表面温度と各土地被覆との相関関係

\begin{tabular}{c|c}
\hline & 地表面温度 \\
\hline 水域 & -0.19 \\
影域 & 0.61 \\
水田 & -0.36 \\
畑 & 0.12 \\
樹木 & -0.55 \\
草地 & -0.22 \\
土壌 & 0.00 \\
アスファルト & 0.62 \\
コンクリート & 0.52 \\
瓦屋根 & 0.75 \\
金属 & 0.40 \\
\hline
\end{tabular}

卜分類と比較して，影域，畑，土壤，コンクリート， 瓦屋根，金属のように飛躍的に精度が向上した被覆が あるのに対して，水田，草地，アスファルトなどで精 度が一部低下してしまった。これについては今後，精 度の低下した被覆については，取得方法などを検討す ることによって精度の改善を試みる必要がある。

\section{4. 詳細土地被覆情報と地表面温度との関係}

ここでは，前章で行ったオブジェクト分類手法によ る土地被覆分類の結果とASTER衛星で撮影された地表 面温度との関係を分析する。分析方法としては, ASTER衛星画像の地表面温度の分解能に合わせて $90 \mathrm{~m} の$ メッシュを作成し，この各メッシュ内に含まれる各土地 被覆面積割合と地表面温度との関係をみる.

\section{(1) OLSIによる土地被覆面積割合と地表面温度との関係}

ASTER衛星の地表面温度画像を用いて，各土地被覆 面積割合との関係性をOLSによって分析した。OLSの基 本式は以下となる.
表-3 OLSによる結果

\begin{tabular}{|c|c|c|}
\hline 説明変数 & 係数 & \\
\hline 水域 & $\begin{array}{c}-10.56 \\
(-16.53)\end{array}$ & $* *$ \\
\hline 影域 & $\begin{array}{c}4.25 \\
(3.46)\end{array}$ & $* *$ \\
\hline 水田 & $\begin{array}{c}-6.04 \\
(-9.74)\end{array}$ & $* *$ \\
\hline 畑 & $\begin{array}{l}27.22 \\
(9.20)\end{array}$ & $* *$ \\
\hline 樹木 & $\begin{array}{c}-6.70 \\
(-11.35)\end{array}$ & $* *$ \\
\hline 草地 & $\begin{array}{c}-1.22 \\
(-1.80)\end{array}$ & \\
\hline 土壌 & $\begin{array}{l}-1.89 \\
(-2.89)\end{array}$ & $* *$ \\
\hline アスファル & $\begin{array}{c}3.89 \\
(4.37)\end{array}$ & $* *$ \\
\hline コンクリート & - & - \\
\hline 瓦屋根 & $\begin{array}{l}11.34 \\
(9.50)\end{array}$ & $* *$ \\
\hline 金属 & - & - \\
\hline 定数項 & $\begin{array}{c}39.67 \\
(70.38)\end{array}$ & $* *$ \\
\hline $\mathrm{R}^{2}$ & 0.73 & \\
\hline Adj.R ${ }^{2}$ & 0.73 & \\
\hline 水プル数 & 2214 & \\
\hline
\end{tabular}

$y_{i}$ : 被説明変数, $\beta_{0}$ : 定数項, $\beta_{n}$ : 推定される係数, $x_{i n}$ : 説明変数, $\varepsilon_{i}$ : 誤差項, $i:$ 各メッシュ

本研究では，説明変数を各メッシュに含まれる11項目 の土地被覆面積の割合，被説明変数を地表面温度とした。 また，分析を行う際に，多重共線性が発生した場合は， 増減法を用いて変数選択を行った. 
表-4 GWRによる結果

\begin{tabular}{c|ccccc}
\hline & Min. & 1stQu. & Median & 3rdQu. & Max. \\
\hline 水域 & -28.83 & -10.79 & -4.16 & 3.09 & 44.50 \\
影域 & -75.52 & -3.52 & 2.97 & 11.07 & 89.27 \\
水田 & -248.40 & -9.96 & -4.38 & 1.93 & 381.90 \\
樹木 & -37.33 & -9.39 & -4.85 & -0.66 & 29.05 \\
草地 & -38.33 & -5.41 & -0.79 & 3.39 & 40.24 \\
土壤 & -28.88 & -5.05 & -1.09 & 3.36 & 40.24 \\
アスフアル & -40.44 & -2.26 & 2.03 & 6.81 & 41.03 \\
瓦屋根 & -37.41 & 1.39 & 6.26 & 12.61 & 61.12 \\
金属 & -70.82 & -5.28 & 1.07 & 7.45 & 101.20 \\
\hline 観測数 & \multicolumn{5}{c}{} \\
バンド幅 & \multicolumn{7}{c}{2214} & \\
$\mathrm{R}^{2}$ & & 196.44 & & \\
\hline
\end{tabular}

Min.(最小值），1st Qu. （第一四分位）， Median（中央值） 3rdQu.（第三四分位），Max.（最大值）

表-2に，地表面温度と各土地被覆との関係を相関表に 示す.これにより，それぞれ地表面温度に対して各土地 被覆がどのような関係にあるのかを正負の相関として判 定できる.

表-3に，OLSによる結果を示す。この結果，補正済み 決定係数は 0.73 と高い関係がみられた。得られた係数は 表-2の相関表と同じように，地表面温度に対して負の影 響を表しているものは水域，水田，樹木，草地であり， 一方で正の影響を与えているのは影域, 畑, アスファル 卜，瓦屋根であった。コンクリートと金属は，OLSでは 変数として採用されなかつたが，表-2の相関表から正の 関係にあることが分かる.土壌については，相関関係が 顕著でないため，正負の関係が明確には分からなかった。

\section{(2) GWRIよる土地被覆面積割合と地表面温度との関係}

前節では，OLSにより各土地被覆割合と地表面温度と の関係を把握した。しかし，OLSでは空間的に変動する 係数の空間的異質性を除外し，被説明変数亡説明変数の 関係を平均的な傾向として係数が得られる. そこで，こ こではGWRを用いて, 各土地被覆割合と地表面温度と の関係性を分析する. その方法は大西ら ${ }^{24) や B u y a n t u y e v ~}$ and $\mathrm{Wu}^{25)}$ を参考にした. GWRは係数の空間的変動を考慮 しており，指標や得られる相関関係の持つ地域的意味の 適切な理解や高い予測精度のモデルの作成に役立つ. こ のモデルの特徵は, 地理空間上の各地点における近隣の 観測情報を部分サンプルとして局所的に重み付けを行う ものである24. GWRの基本式は以下のように表すことが できる.

$$
W_{i} y=W_{i} X \beta_{i} \times \varepsilon_{i}
$$

$y$ : 被説明変数, $X$ : 説明変数の行列, $\varepsilon_{i}$ : 誤差項, $W_{i}$ :

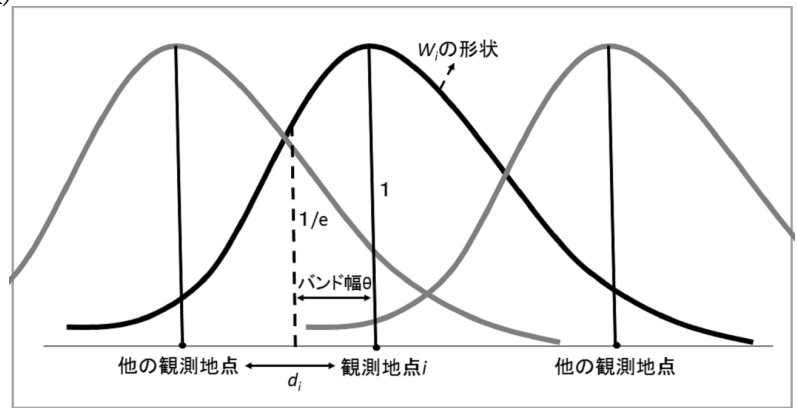

図-3ＧWR の概念図

則内 ${ }^{32}$ の論文を参考に作成

空間的重文行列

GWRは，OLSの基本式に座標系を組み込んだ拡張モ デルである. $\beta_{i}$ は観測地点 $i$ における要素数 $\mathrm{k}-1$ の回帰 係数ベクトルである ${ }^{30)}$. $\beta_{i}$ は次式で表すことができる.

$$
\hat{\beta}=\left(X^{\prime} W_{i}^{2} X\right)^{-1}\left(X^{\prime} W_{i}^{2} y\right)
$$

また，観測地点からの距離に応じて変動させる重み付 け行列 $W_{i}$ は, ガウス型の距離低減関数を用いた次式で 表すことができる.

$$
W_{i}=\exp \left(-\left(d_{i} / \theta\right)^{2}\right)
$$

$d_{i}$ : 観測地点 $i$ から他の観測地点までの距離, $\theta$ : 最適バ ンド幅（パラメータ）

最適バンド幅 $\theta$ は距離低減関数において唯一のパラメ 一タである. なお, 最適なバンド幅を探索する方法とし ては，次式で与えられるクロス推計（The Cross-Validation

(CV) Score) 法が提案されている24),31)。これは，観測 地点 $i$ の推定值を, この観測地点 $i$ を除いた周辺サンプル におけるその他の観測地点データを利用して推計する方 法であり， $\theta$ について最小化する24,31). 本研究でも, こ のクロス推計法を用いた。 図-3にGWRの概念図を示す. 
表-5 土地被覆項目ごとの係数の出現数と分布

\begin{tabular}{|c|c|c|c|c|c|c|c|c|c|c|c|c|c|}
\hline & & & & & 水域 & 影域 & 水田 & 草地 & 樹木 & 土壤 & アスファル & 瓦屋根 & 金属 \\
\hline-30 & $\leqq$ & $\beta$ & $<$ & & 0 & 65 & 109 & 8 & 5 & 0 & 9 & 5 & 54 \\
\hline-30 & $<$ & $\beta$ & $\leqq$ & -20 & 63 & 56 & 45 & 38 & 50 & 12 & 28 & 19 & 60 \\
\hline-20 & $<$ & $\beta$ & $\leqq$ & -15 & 202 & 42 & 87 & 97 & 114 & 41 & 42 & 12 & 58 \\
\hline-15 & $<$ & $\beta$ & $\leqq$ & -13 & 163 & 27 & 122 & 52 & 130 & 38 & 19 & 16 & 54 \\
\hline-13 & $<$ & $\beta$ & $\leqq$ & -10 & 191 & 68 & 187 & 73 & 199 & 77 & 43 & 16 & 85 \\
\hline-10 & $<$ & $\beta$ & $\leqq$ & -7.5 & 187 & 88 & 233 & 101 & 263 & 145 & 58 & 27 & 107 \\
\hline-7.5 & $<$ & $\beta$ & $\leqq$ & -5 & 228 & 112 & 251 & 223 & 326 & 250 & 124 & 78 & 160 \\
\hline-5 & $<$ & $\beta$ & $\leqq$ & -2.5 & 199 & 163 & $\underline{258}$ & 302 & $\underline{352}$ & 333 & 207 & 116 & 196 \\
\hline-2.5 & $\leq$ & $\beta$ & $\leqq$ & 0 & 193 & 211. & 220 & $\underline{338}$ & 306 & 360 & 311 & 153 & 228 \\
\hline 0 & $<$ & $\beta$ & $\leqq$ & 2.5 & 188 & 221 & 194 & 330 & 245 & 309 & $\underline{327}$ & 237 & $\underline{24}$ \\
\hline 2.5 & $<$ & $\beta$ & $\leqq$ & 5 & 183 & $\underline{225}$ & 125 & 249 & 109 & 242 & 303 & $\underline{295}$ & 211 \\
\hline 5 & $<$ & $\beta$ & $\leqq$ & 7.5 & 123 & 186 & 75 & 137 & 48 & 138 & 243 & 259 & 208 \\
\hline 7.5 & $<$ & $\beta$ & $\leqq$ & 10 & 82 & 150 & 50 & 80 & 22 & 109 & 156 & 242 & 128 \\
\hline 10 & $<$ & $\beta$ & $\leqq$ & 12.5 & 74 & 118 & 38 & 49 & 16 & 79 & 88 & 180 & 85 \\
\hline 12.5 & $<$ & $\beta$ & $\leqq$ & 15 & 43 & 94 & 37 & 34 & 13 & 29 & 67 & 119 & 55 \\
\hline 15 & $<$ & $\beta$ & $\leqq$ & 20 & 29 & 170 & 37 & 45 & 11 & 24 & 93 & 173 & 71 \\
\hline 20 & $<$ & $\beta$ & $\leqq$ & 30 & 35 & 137 & 45 & 48 & 5 & 20 & 77 & 172 & 86 \\
\hline 30 & $<$ & $\beta$ & $\leqq$ & 40 & 26 & 55 & 22 & 8 & 0 & 7 & 18 & 66 & 80 \\
\hline 40 & $<$ & $\beta$ & $\leqq$ & 50 & 5 & 12 & 16 & 2 & 0 & 1 & 1 & 26 & 26 \\
\hline 50 & $<$ & $\beta$ & $\leqq$ & 75 & 0 & 10 & 9 & 0 & 0 & 0 & 0 & 3 & 12 \\
\hline
\end{tabular}

ここで，最適バンド幅 $\theta$ は観測地点（回帰地点）ごとの 勢力範囲とも言うことができ，大きいほど各観測地点の パラメータ推定で利用される近傍の範囲が広くなり，大 きければなめらかなパラメータの空間変異が，小さけれ ば凹凸の激しい局所的な区間変異が得られる33)。一般に バンド幅が大きければパラメータ推定の際に利用するデ ータ量は多くなり，パラメータ推定值の信頼性が向上寸 る一方で，パラメータ変異の空間的分解能は落ちてしま う33)。バンド幅が小さければパラメータ変異の分解能は 高く, 現実のデータにより適合するものの，パラメータ 推定値は統計的な信頼性に欠けたものになってしまう33). このスケール問題を解くため，前述のクロス推計法を用 いている.

$$
C V(\theta)=\sum_{i=1}^{n}\left\{y_{i}-\hat{y}_{\neq i}(\theta)\right\}^{2}
$$

表-4に，GWRによる結果を示す．この結果，OLSの結 果における全体地域の重決定係数 $\left(\mathrm{R}^{2}\right)$ と比較すると, GWRの結果が0.92とその向上がみられる. 最適バンド幅

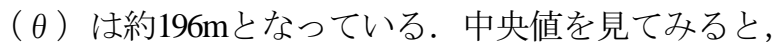
水域，水田，樹木，草地，土袞の係数が負となっている のに対し，影域，アスファルト，瓦屋根，金属は係数が 正となっている. OLSによる水田の係数は負であったが, GWRの結果から水田の係数のうち $25 \%$ までは正となっ ている. アスファルトの係数についても，OLSの結果で
表-6 地表面温度の基本統計量

\begin{tabular}{l|c|c|c}
\hline & ASTER 衛星 & OLS 再現 & GWR 再現 \\
\hline 平均值 & 38.96 & 39.07 & 38.94 \\
標準誤差 & 0.08 & 0.07 & 0.07 \\
中央值 & 40.25 & 39.80 & 40.25 \\
標準偏差 & 3.68 & 3.10 & 3.44 \\
分散 & 13.51 & 9.62 & 11.86 \\
最小 & 25.85 & 29.32 & 27.01 \\
最大 & 47.55 & 44.79 & 44.90 \\
\hline
\end{tabular}

表-7 地表面温度の相関係数

\begin{tabular}{l|c|c|c}
\hline & ASTER LST & OLS LST & GWRLST \\
\hline ASTER 衛星 & 1.00 & & \\
OLS 再現 & 0.85 & 1.00 & \\
GWR 再現 & 0.96 & 0.92 & 1.00 \\
\hline
\end{tabular}

表-8 各地点の地表面温度

\begin{tabular}{lcccc}
\hline & 1 & $(2)$ & $(3)$ & $(4)$ \\
\hline ASTER 衛星 & $43.80^{\circ} \mathrm{C}$ & $47.60^{\circ} \mathrm{C}$ & $31.50^{\circ} \mathrm{C}$ & $37.90^{\circ} \mathrm{C}$ \\
OLS 再現 & $41.90^{\circ} \mathrm{C}$ & $40.90^{\circ} \mathrm{C}$ & $34.50^{\circ} \mathrm{C}$ & $38.20^{\circ} \mathrm{C}$ \\
GWR 再現 & $43.90^{\circ} \mathrm{C}$ & $43.20^{\circ} \mathrm{C}$ & $32.60^{\circ} \mathrm{C}$ & $37.60^{\circ} \mathrm{C}$ \\
\hline
\end{tabular}

はすべて正となっていたものの，GWRの結果では係数 の $25 \%$ ま゙が負となっている，このことから，対象地域 全体における水田の係数の傾向が概福であっても，地 域によっては正の影響になることが分かった.

次に係数の分布をさらに詳しく見るため，土地被覆項 目ごとの係数の出現数と分布を表-5に示す. 水田の最大 值は381.90であり，最小值は-248.40となっているが，正 負の境界付近の出現数を強調するため, 係数の-30以下 と75以上の分布についてはここでは割愛する. 下線は最 


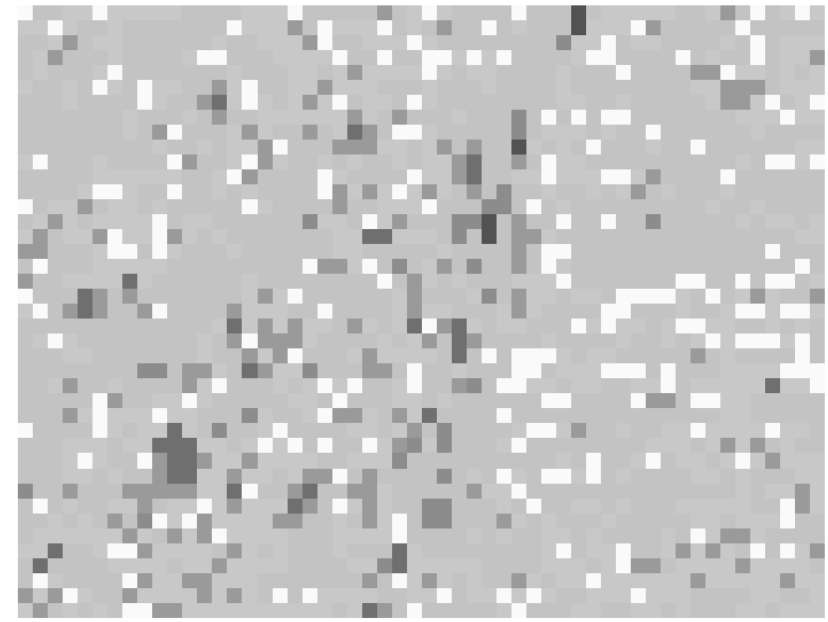

図-4 ASTER と OLS の地表面温度の比較

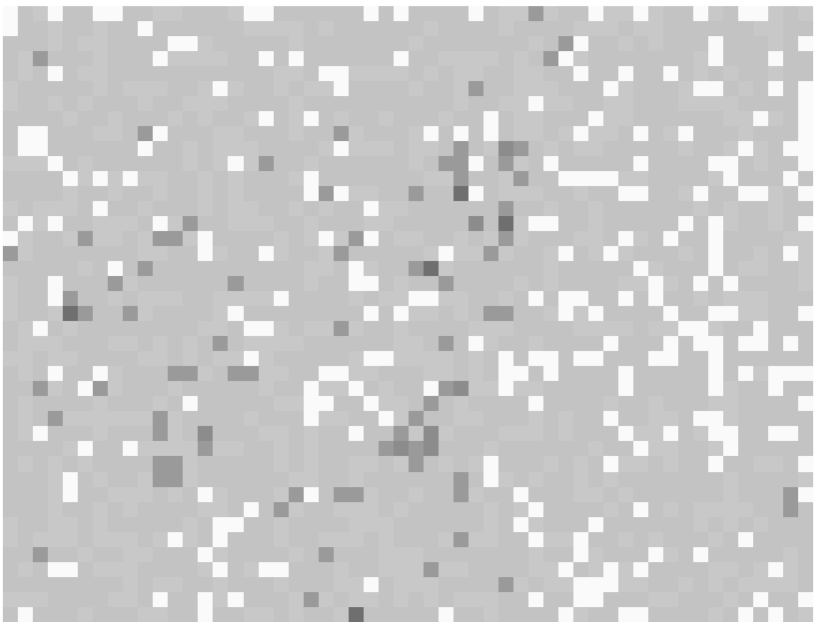

図-5ＡSTER と GWR の地表面温度の比較

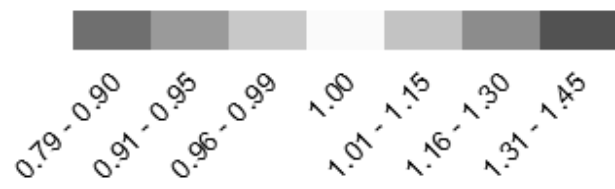

大出現数を示し, 中央の点線は正負の境界を表している この結果，全体的な傾向をみてみると，同じ自然的な土 地被覆であっても，水域，水田，樹木などはどちらかと いうと負の係数が高いものが多いのに対して，草地や土 壌は負の係数が低いことが分かる. とりわけ係数が負と なっている自然的な土地被覆のうち，より低い係数で観 測地点の最大出現数が分布しているのは水域であり, 対 象地域において水域の温度低減効果が高いことが示され た. 他方, 係数が正の值で分布しているアスファルトと 瓦屋根をみてみると, 瓦屋根の係数の分布がアスファル トよりも正の值が高くなっていることが分かる．この一 つの要因として, 富山県では比較的アルベドの高い黒色 の瓦屋根が使用されていることに由来していると考えら れる.

\section{(3) OLSとGWRIよよる地表面温度の再現結果}

ここでは，OLSとGWRの結果から導出された関係式 を用いて地表面温度を再現する。まず，表-6にASTER衛 星画像による地表面温度及びOLSとGWRによる地表面 温度の再現結果の基本統計量を示す。これを見ると， ATER衛星画像による地表面温度の平均值と中央值は, GWRの再現結果の方がOLSのそれより近いことが分か る.ただし，GWRによる最大と最小の地表面温度の再 現結果は, ASTER衛星画像のそれと比較してその範囲 が狭くなっており，これが標準偏差や分散にも表れてい ると考えられる．ただし，ここでもGWRの再現結果の 方がOLSよりASTER衛星画像に近いことが分かる.

次に, 表-7にASTER衛星画像による地表面温度及び OLS とGWRによる地表面温度の再現結果の相関関係を 示寸。この結果, ASTER衛星画像の地表面温度と相関
関係が強いのはOLSの再現結果よりGWRのそれである ことが分かり，前述した基本統計量の結果をより明確に 表していることが分かる. また，図-4にOLSの地表面温 度の再現結果をASTER衛星画像による地表面温度で除 したものを，同様に図-5にGWRの地表面温度の再現結 果をASTER衛星画像による地表面温度で除したものを 示す.この結果, ASTERの地表面温度画像と適合して いる地域，すなわち1.00となる地域はGWRが456（全体 の20.60\%）であり，OLSが241（全体の10.89\%）と明ら かにGWRの方が再現精度が高いことが分かる。また， GWRはOLSより1.00の前後における地域が多いのが一見 して分かり，全体的に薄い色合いとなっていることが見 てとれる.

次に，個別の地域の特色を具体的に見るため，図-6に 対象地域全体のトゥルーカラー画像を，図-7にASTER衛 星による地表面温度画像を示す。また, 図-8 と図-9に OLSとGWRの再現結果を示す. 図-6における左側の白円 は水田地域周辺を示しているが，その周辺温度分布に着 目寸ると, 図-7では周辺から中心部へかけて地表面温度 が低下していることが分かる. 他方，この傾向を再現画 像である図-8及び図-9と比較すると, 図-8では水田地域 周辺の地表面温度の高低が平滑化され，図-7のような傾 向はほとんどみられない，図-9では，近接するメッシュ の影響で図-7の地表面温度分布に近づいていることが分 かる. また, 図-7, 図-8, 図-9の(1)，(2)，(3)，(4)の地点 での地表面温度をそれぞれ比較したものを表-8に示す.

(1)，(2)，(3)地点ではOLSに比べGWRによって再現され た地表面温度が実際の地表面温度に近いことが分かる。 他方, (4)地点については実際の地表面温度がGWR と OLSの中間の值となり，地域によっては必ずしもGWR 


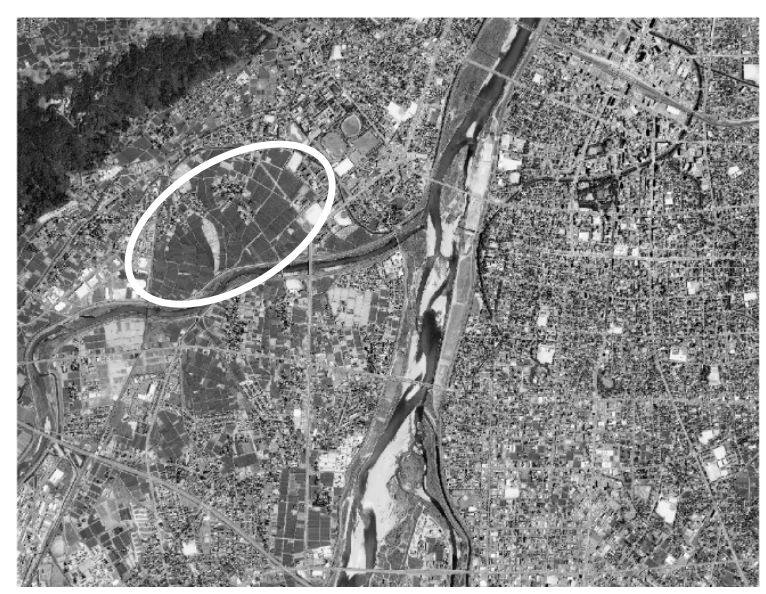

図-6 トゥルーカラー画像

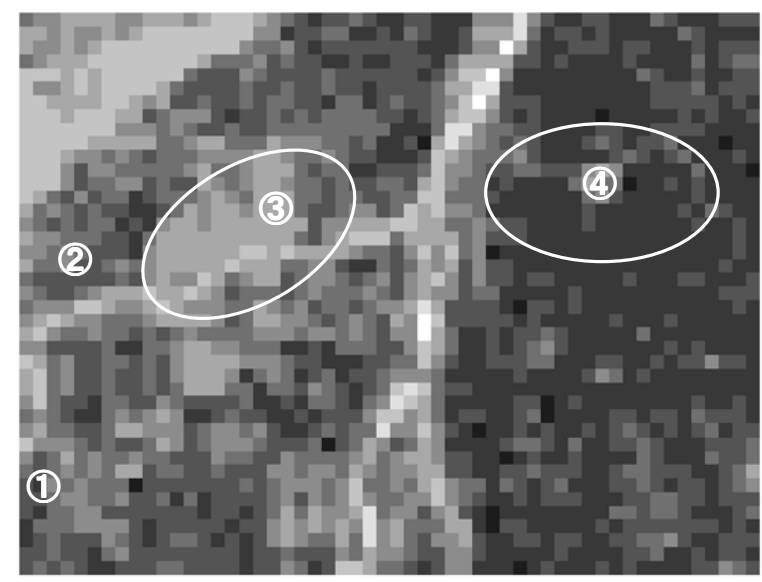

図-8 地表面温度画像（OLS の結果）

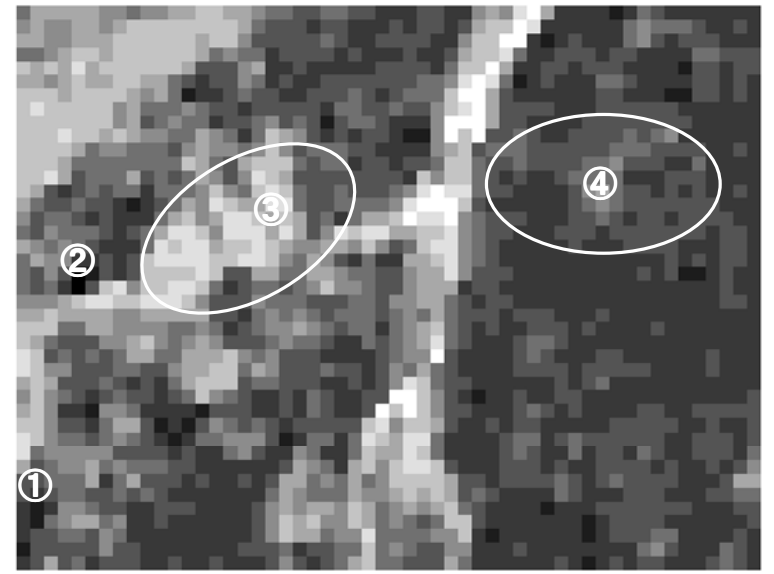

図-7＼cjkstart地表面温度画像（ASTER 衛星）

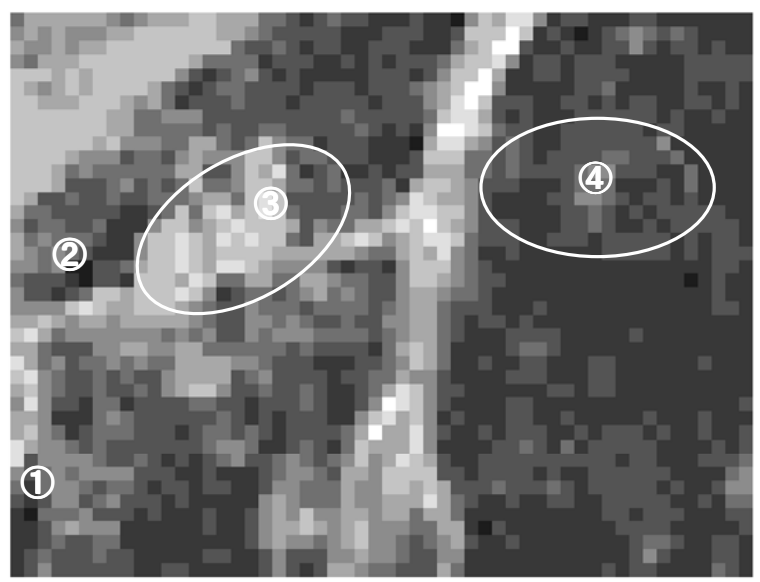

図-9＼cjkstart地表面温度画像（GWR の結果）

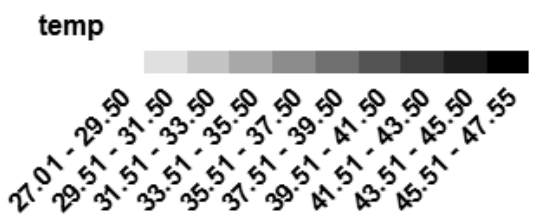

の再現性が高いとは言えない場合があることが示唆され た. しかし，温度分布の傾向や表-6〜8の結果からも分 かるように，全体的には地域ごとに係数を決定していく GWRによる再現性がOLSよりも圧倒的に高いことが明 らかになった。

\section{5. おわりに}

本研究では, 熱環境の原因となっている土地被覆の情 報をできる限り詳細に取得するため，既存のピクセルベ 一スの分類手法ではなく, 新たな分類手法として近年利 用されているオブジェクト分類手法を試みた。 そして, このオブジェクト分類手法を用いて得られた詳細な土地 被覆の結果を現地の情報と照らし合わせることによって 精度検証を行った. さらに, 従前の我々のピクセルベー スによる分類結果と比較することによってその精度の高
さを示した。ささらに，得られた土地被覆分類の結果と夏 季の昼間における地表面温度との関係を明らかにするた め，通常一般に用いられるOLSの手法に加えて，地理的 に固有の係数を得ることができるGWRを用いることに よって地域の特徵を加味した関係式を導出した．最終的 には，これら異なる結果によって再現された地表面温度 と，ASTER衛星画像の地表面温度を比較することによ って，GWRによる再現性の高さを示した。これによっ て本研究では, 精度の高い詳細な土地被覆の情報を取得 する方法を提示するとともに，地表面温度を再現する新 たな手法を示した.

今後の課題を以下にまとめる.

1) オブジェクト分類手法は 1 オブジェクトあたりにお いて面積の小さな瓦屋根や住宅地に発生する影域な どで誤分類が発生する可能性がある。こうした改善 には，スケールレベルやマージレベルの設定などを 厳密に行う必要がある.ただし，研究の目的に応じ 
て精度高く取得したい土地被覆を中心に設定を行う 必要があり，この点を踏まえて慎重にレベルの設定 を行う必要があると考えられる。

2) 今回，富山市の中心市街地を対象にしたが，ここで 得られた結果が地域固有の特徵なのか，もしくはど の地域でも同様の結果がみられるのかは分からない. そのため, 出来る限り多くの地域で分析を行うこと で分類手法及び統計的な手法の汎用性についても十 分に考慮していきたい.

3) 本研究では, GWRを用いることで地域によって得 られる係数が異なることを示し, 地表面温度の再現 性が通常のOLSよりも高いことを示した。しかし， この係数の違いが土地被覆以外の他の要因, 例えば 植生の活性具合や地形起伏などに起因している可能 性があり，今後はこれらの要因を明らかにする必要 がある。これによって地表面温度を形成している土 地被覆以外の要因を知ることによって熱環境を緩和 していくための方策を考える上で重要な情報となり 得ると考えられる.

謝辞 : 本研究は, 科学研究費補助金 (26340104, 代表 : 大西暁生）と環境省の環境研究総合推進費 (3K143015, 代表 : 田畑智博）の支援により実施された。 また，查読 者から貴重なご意見を頂いた。ここに記して，深謝する。

\section{参考文献}

1) 足永靖信，李海峰，尹 聖皖：顕熱潜熱の違いを考慮した 東京 23 区における人工排熱の排出特性に関する研究，空 気調和・衛生工学会論文集, NO.92, pp.121-130, 2004.

2) 尾島俊雄 : 暑くなる大都市, NHKブックス, 1975.

3) 鳴海大典, 大谷文人, 近藤明, 下田吉之, 水野稔: 都 市における人工廃熱が都市熱環境に及ぼす影響一都市熱 環境評価モデルを用いたヒートアイランド現象の改善策 に関する検討その 1 -, 日本建築学会計画系論文集, No. 562, pp.97-104, 2002.

4) 三上岳彦: 都市のヒートアイランド現象とその形成要因 : 東京首都圈の事例研究，地學雜誌 114 （3），pp. 496-506, 2005.

5) 松本太, 一八瀬俊明, 白木洋平, 李龍太 : 都市内河川の 大規模復元による「風の道」の効果に関する気候学的研 究一韓国ソウル市清溪川を事例として一, 日本生気象学 会雑誌，Vol.46，No.2，pp.69-80， 2009.

6) 山口隆子 : 屋上緑化の推進に向けて, 予防時報, 245, pp. 14-19, 2011.

7) 名古屋市「緑化地域制度について」 http://www.city.nagoya.jp/ryokuseidoboku/page/0000008169.html.

8) 近藤靖史, 小笠原岳, 大木泰祐, 有働邦広: 建物屋根
面の日射反射性能向上によるヒートアイランド緩和効果, 日本建築学会環境系論文集 Vol.73，No.629，pp.923-929, 2008.

9）近藤靖史, 長澤康弘, 人交麻衣子：高反射率塗料による 日射熱負荷軽減とヒートアイランド現象の緩和に関する 研究, 空気調和・衛生工学会論文集, No.78, pp. 15-24,

2000.

10）天野智順，中川敬介 : ランドサットデータを用いた都市 域の気温と土地被覆との関連性, 富山県立大学紀要 17, pp.108-113, 2007.

11）渡辺浩文, 依田浩敏, 尾島俊雄: リモートセンシングデ 一夕と数值情報利用による広域都市の地表面温度分布図 の作成に関する研究，日本建築学会計画系論文報告集， No.443, pp.21-29, 1993.

12) 円満隆平, 尾島俊雄: 気象衛星による市街地熱環境調 查: リモートセンシングによる都市空間の構造解析（その 2），日本建築学会論文報告集，No. 334，pp. 101-108， 1983.

13）大西暁生, 廣田福太郎, 吉川拓未, 森杉雅史, 井村秀 文: 高分解能衛星画像を用いた詳細土地被覆情報と輝度 温度との関係一緑地の特性に着目して一, 環境システム 研究論文集, Vol.31, pp.357-365, 2003.

14）大西暁生, 松浦未央子, 森杉雅史, 井村秀文 : LANDSAT $\mathrm{ETM}+$ 画像におけるヒートアイランド現象の把握と IKONOS 画像を用いた特殊空間緑化の熱環境緩和効果に関 する研究, 環境共生学会審查付研究発表論文, Vol. 10, pp.92-102, 2005.

15）大西暁生, 森杉雅史, 林良嗣, 井村秀文 : 詳細土地被覆 情報を用いた土地利用別ヒートアイランド緩和効果に関 する研究. 環境の管理, Vol.61, pp.23-35, 2006.

16）大西暁生, 森杉雅史, 村松由博, 井村秀文, 林良嗣: 愛 知県豊田市における詳細土地被覆情報の取得と熱環境解 析一の適用に関寸る研究, 地球環境研究論文集, pp.181190, 2008.

17）大西暁生, 曹金金, 森杉雅史, 奥岡桂次郎, 井村秀文 : 名 古屋市中心地における空閑地緑化による都市熱環境緩和 効果，都市計画報告集，No.8-4, pp.176-180, 2010.

18）大西暁生，森杉雅史 : 名古屋市中心部における空閑地緑 化が都市熱環境緩和効果に与える影響, 社会技術研究論 文集，Vol. 8, pp.149-158，2011.

19) A. Onishi, X. Cao, T. Ito, F. Shi and H. Imura: Evaluating the potential for urban heat-island mitigation by greening parking lots, Urban forestry \& Urban greening, Vol. 9 (4), pp.323-332, 2010.

20）廣田福太郎, 大西暁生, 森杉雅史, 井村秀文 : 高分解能 衛星を用いた都市内緑地分析に関する研究, 環境システ 八研究論文集, Vol.30, pp.91-99, 2002.

21) X. Cao, A. Onishi, J. Chen and H. Imura: Quantifying the cool island intensity of urban parks using ASTER and IKONOS data, Landscape and urban planning, Vol. 96, pp. 224-231,2010. 
22）吉川拓未，廣田福太郎，大西暁生，森杉雅史，井村秀 文 : 都市域の熱環境解析のための詳細土地被覆情報に関 する基礎的研究. 環境システム研究論文発表会講演集, 31, 591-597, 2003.

23）上野賢仁，井村秀文 : 名古屋市域を対象とした高分解能 衛星画像による土地被覆と衛星輝度温度の解析. 環境シ ステム研究論文発表会講演集, Vol.32, pp.537-542， 2004.

24）大西暁生，奥岡桂次郎，石峰，森杉雅史 : 地理的加重回 帰法を用いた緑地の熱環境緩和効果の季節・空間特性の 把握，都市計画報告集，No.9-3，pp.93-97，2010.

25) Buyantuyev, A., Wu, J. : Urban heat islands and landscape heterogeneity: linking spatiotemporal variations in surface temperatures to land-cover and socioeconomic patterns. Landscape Ecology, Vol. 25, pp.17-33,2010.

26）奥岡桂次郎，大西暁生，谷川寛樹，白川博章 : 歴史的景 域の経済的評価に関寸る研究 - 名古屋市における神社周 辺の緑地のへドニック・アプローチ - ，土木学会論文集 G (環境)，Vol. 67 No. 5, 地球環境研究論文集第 19 巻, pp.I_273 - I_279, 2011.

27) 大西暁生, 前崎隆一 : 富山市中心市街地における詳細土 地被覆情報取得のための分類手法の比較・検討，東京都
市大学横浜キャンパス紀要, Vol. 1, pp.53-62,2014.

28）越智士郎：画像オブジェクトに基づく高分解能衛星画像 での土地被覆分類手法の検討，東南アジア研究，VOl. 46, No.4, pp.578-592, 2009.

29) 王文君, 岸田忠大, リュウ・ウェン, 山崎文雄 : 空中写 真を用いたオブジェクト指向の建物被害手法の検討,

(社) 日本リモートセンシング学会第 52 回（平成 24 年度 春季）学術講演会, 2012.

30) 谷村 晋（著），金 明哲（編集）：地理空間データ分析 （R で学ぶデータサイエンス 7)，共立出版，pp.157-160, 2010.

31) 大庭哲治, 柄谷友香, 中川大, 青山吉隆 : 京町家集積に よる外部効果の空間特性に関する研究，Vol. 60-4, pp.481482, 2005.

32) 則内良太 : 地理的加重回帰モデルを用いた住宅価格の形 成要因に関寸る研究, 九州大学大学院修士論文, 2008 .

33）杉浦 芳夫（編）：地理空間分析（シリーズ・人文地理学 3）第3版, 朝倉書店, pp.157-160, 2010.

\section{Acquiring of Fine Land Covers Information by Using the Object Based Classification Method, and Examination of Reproducibility of Land Surface Temperature}

\section{Akio ONISHI ${ }^{1}$ and Ryuichi MAEZAKI ${ }^{2}$}

${ }^{1}$ Faculty of Environmental Studies, Tokyo City University

${ }^{2}$ Public officer

The problem of heat environment in urban area has become more obvious recently. One of the causes of this problem relates to the urban land covers. Especially, artificial land surfaces such as concrete, asphalt and so on have been expanded under urbanization and have made the problem more worsen continuously. Therefore, this study firstly acquired the fine land cover information by using the object based classification method which has become popular recently. Then, the acquiring land cover information was verified the accuracy compared with actual land covers. Moreover, relationship between land cover information and land surface temperatures were analyzed by two different statistical methods of the ordinary least squares and the geographically weighted regression. Finally, the reproducibility of the land surface temperatures by both methods were examined. 